\title{
EXTRACTION OF GUM FROM ABELMOSCHUS ESCULENTUS: PHYSICOCHEMICAL PECULIARITY AND ANTIOXIDANT PREPATENT
}

\author{
MEENU NAGPAL ${ }^{1 *}$, GEETA AGGARWAL ${ }^{2}$, UPENDREA K JAIN ${ }^{1}$, JITENDER MADAN $^{1}$
}

${ }^{1}$ Department of Pharmaceutics, Chandigarh College of Pharmacy, Mohali - 140 307, Punjab, India. ${ }^{2}$ Department of Pharmaceutics, Delhi Pharmaceutical Sciences and Research University, New Delhi - 110 017, India. Email: meenu.nagpal51@gmail.com

Received: 18 April 2017, Revised and Accepted: 25 May 2017

\section{ABSTRACT}

Objective: This study is aimed to extract gum from Abelmoschus esculentus using ultrasonic assisted method and exploring physicochemical, functional, and antioxidant potential of gum for food and pharmaceuticals.

Materials and Methods: The extraction of gum from okra was done employing ultrasound-assisted method to improvise the yield. The extracted gum was further characterized for physical properties including swelling index, solubility, water sorption time, packing and flow properties, electrical properties, zeta potential, scanning electron microscopy, and antioxidant activity.

Results: The extraction yield of okra fruit gum (OFG) was found to be $31.52 \% \pm 0.22 \%(n=3)$. The OFG powder obtained after lyophilization showed good flow properties as determined from the results of angle of repose (34.21 $)$, Hausner ratio (1.14), and \% compressibility (12.5\%). An increase in solubility and swelling index of OFG with increase in pH of buffer from 2.0 to 7.4 was observed. The freeze dried OFG possess rough surface and zeta potential of $-9.85 \mathrm{mV}$. Application of derivatized/interacted OFG gum for modification of drug release profiles is concluded from high degree of esterification of 7.8 .

Conclusion: The result suggest that the antioxidant activity of OFG was higher compared to corn flour gum. Thus, OFG could be utilized as natural antioxidant food ingredients and also for application in medicine and health-care products.

Keywords: Okra, Extraction, Ultrasound, Optimization, Antioxidant, Abelmoschus esculentus.

(C) 2017 The Authors. Published by Innovare Academic Sciences Pvt Ltd. This is an open access article under the CC BY license (http://creativecommons. org/licenses/by/4. 0/) DOI: http://dx.doi.org/10.22159/ajpcr.2017.v10i9.19260

\section{INTRODUCTION}

Gums are natural polysaccharides in which multiple sugar units are interconnected together to form large molecules. Gums possess the capability of forming extremely thick aqueous solution or dispersions. Gums in drug delivery have been explored for modifying the drug release rate. Gums have been explored for their use in controlled release dosage forms [1], buccal patches [2], medicated chewing gum [3], biodegradable microparticles [4], nanoparticles [5], stabilized submicron emulsions [6], ion activated in situ gel [7], and many more. Gums attract the attention of researchers because of biocompatibility, abundant availability, stability, hydrophilicity, and its nature of modifiable biopolymers.

Okra fruit gum (OFG) is procured from fruits of Abelmoschus esculentus (family - Malvaceae) and is cultivated in tropical, subtropical, and warm temperate regions worldwide. OFG contains D-galactose, L-rhamnose, and L-galacturonic acid [8,9]. The main structural elements of okra polysaccharide were described by Tomada, Shimada, Saito, and Sugi (1980) who concluded that it contained a repeating unit of alternating $\alpha$-(1-2)-linked rhamnosyl and $\alpha$-(1-4)-linked galacturonic acid residues with a disaccharide side chain of $\beta$-(1-4)-linked galactosyl moieties attached to 0-4 of about half the L-rhamnosyl residues [10] and degree of acetylation up to 58 (DA $=58)[10,11]$. Okra gums are used as thickeners and flavoring for different foods. Polysaccharides extracted from okra are also used as egg white substitute [12] and fat substitute in chocolate bars and frozen dairy desserts $[13,14]$. When extracted in water, it can produce highly viscous solution with a slimy appearance. Okra mucilage is also used as soothing emollient medicine in the treatment of diarrhea, dysentery, and gastric ulcer. A cupful of mucilage mixed with a ripe banana is given as a tonic food during the treatment of colitis, cystitis, hepatitis, and jaundice [15]. A gastroprotective effect of the methanolic extract of okra in ethanol-induced gastric ulcer in rats was reported $[15,16]$. OFG is inexpensive, consistent in quality, chemically inert, biodegradable, biocompatible in nature, and reliable in supply $[8,17]$. These attributes of OKG lead to usefulness as excipients in the development of various pharmaceutical formulations [2,8,17-21]. In addition, the highly viscous property of OKG leads the usefulness of it as a drug-release retarding polymer and it is used in the development of sustained-release drug delivery matrices $[8,17]$.

Extraction of gum is usually done with hot water extraction, ultrasound-assisted extraction and microwave-assisted extraction, of which ultrasonic assisted extraction was chosen because of its lower energy consumption, lower consumption of solvents, higher extraction efficiency, and higher level of automation [22-24].

Till date, no thorough investigation occurred on the ultrasonic extraction process of gum from $A$. esculentus fruits. Therefore, in this study, okra gum is extracted from okra fruits using ultrasound assisted technology. Also in this study, physicochemical, functional and antioxidant performances of OFG were explored for its application in food and pharmaceutical industry.

\section{MATERIALS AND METHODS}

\section{Materials}

The fruits of A. esculentus (usually known as bhindi) were purchased from local market (Chandigarh, India). OFG samples being collected were stored in airtight jars in dessicator. All other chemicals used in extraction and characterization of gum were of analytical reagent grade. 
Ultrasonic assisted extraction of OFG from A. esculentus fruits OFG was extracted by modifying the method described by Wang et al., 2014 [22] using an ultrasonic device (AS3120A, Tinjin Automatic Science Instrument Co., Ltd., China). Fruits were cleaned, sliced and were mashed in $2 \% \mathrm{v} / \mathrm{v}$ glacial acetic acid solution to form a slurry and gum was extracted in distilled water in $1000 \mathrm{ml}$ beaker with $1: 1$ ratio of water to raw material, $65 \mathrm{~W}$ ultrasonic power and 45 minutes extraction time at $65^{\circ} \mathrm{C}$. After extraction, the slurry was filtered through muslin cloth to remove debris. Excess acetone was added for precipitating the gum. Finally, the precipitates were dried in vacuum oven at $50^{\circ} \mathrm{C}$. The $\mathrm{OFG}$ sample was further purified by dialysis. Purified gum obtained by lyophilization and ground to OFG gum powder. Each OFG sample was weighed and yield was calculated. The extraction procedure of OFG is summarized in Fig. 1.

\section{Physical characterization of OFG sample}

Swelling index

The OFG sample (100-250 mg) was filled into micropipette tips for evaluating swelling index. The tip outlet was blocked with Nylon fiber swab to avoid leakage of the powder during the testing. OFG sample was tapped 10 times by dropping on a hard surface from a $10 \mathrm{~cm}$ height to obtain the same bed packing. The plastic tip was saturated with distilled water, $\mathrm{HCl}(0.1 \mathrm{~N})$ or phosphate buffer $\mathrm{pH} 1.2,6.8,7.4$ or 10.0, respectively, for $24 \mathrm{~h}$. The plastic tip was weighed $\left(\mathrm{W}_{\mathrm{i}}\right)$ and then dipped into a 2-3 mm layer of deionized water, phosphate buffer $\mathrm{pH}$ 1.2, 6.8 and 7.4, respectively. After the bed was wetted with liquid, the tip was again weighed $\left(\mathrm{W}_{\mathrm{f}}\right)$ to find the amount of the liquid taken in by the powder. The swelling index was estimated using the formula:

$$
\mathrm{SI}=\frac{\mathrm{W}_{\mathrm{f}}-\mathrm{W}_{\mathrm{i}}}{\mathrm{W}_{\mathrm{i}}}
$$

Average value was taken for calculation after repeating the experiment for 6 times.

\section{Solubility}

Powdered OFG ( $2 \mathrm{~g}$ ) was added to $200 \mathrm{ml}$ of distilled water and left undisturbed (10-12 hrs), allowing it to swell totally. After stirring at room temperature $\left(25-30^{\circ} \mathrm{C}\right)$ and elevated temperature $\left(55-65^{\circ} \mathrm{C}\right)$ for approximately 50 minutes, the solution was cooled and centrifuged at $5000 \times g$ for 25 minutes to remove the insoluble material. The settled portion was then moved into a Petri dish and dried at $110^{\circ} \mathrm{C}$ in an oven till stable weight was obtained [2]. The following equation was used to determine solubility:

$$
\text { Solubility }(\%)=\frac{\mathrm{S} 2-\mathrm{S} 1}{\mathrm{~S} 2} \times 100
$$

Where, S1 is the sediment fraction (mg) while S2 is the initial concentration of the solution (mg). Solubility of OFG was also

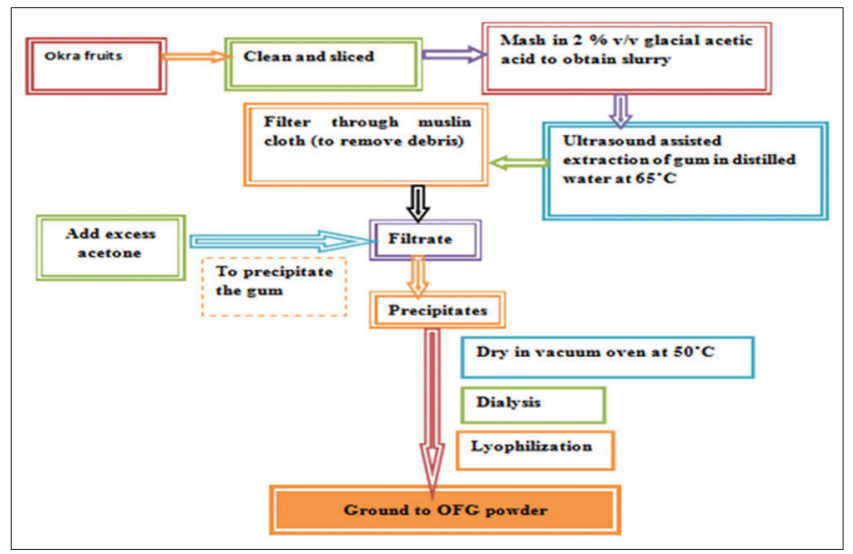

Fig. 1: Extraction procedure of okra fruit gum powder investigated in other solvents such as ethanol, acetone, and chloroform, and in buffers of $\mathrm{pH} 2.0,3.0,4.5,5.0,5.5,6.8,7.4,10.0$.

\section{Water sorption time (WST)}

The OFG $(50 \mathrm{mg})$ was soaked in distilled water, $\mathrm{HCl}(0.1 \mathrm{~N})$ or phosphate buffer $\mathrm{pH} 1.2,6.8$ or 7.4 , respectively $(100 \mathrm{cc})$ for $24 \mathrm{hrs}$. The time taken by the liquid to reach to top of powder bed was estimated as WST $[25,26]$.

\section{Packing and flow properties of OFG}

Angle of repose

The fixed funnel and free standing cone method were employed in which a funnel is secured with its tip at a given height, $\mathrm{H}$, above graph paper that is placed on a flat horizontal surface. OFG powder was precisely weighed and vigilantly introduced into the funnel until the peak of the conical stack just touches the funnel tip. Angle of repose was calculated using the following equation:

$$
\operatorname{Tan} \alpha=\frac{H}{R}
$$

Where, $\mathrm{R}$ is the radius of the base of the conical stack.

\section{Bulk and tapped density}

A known amount of the powdered OFG sample (M) was placed in a measuring cylinder $(100 \mathrm{~mL})$ and the volume $\left(\mathrm{V}_{0}\right)$ occupied by the $\mathrm{OFG}$ sample was noted as bulk volume. The cylinder was then tapped, and the volume occupied after 100 taps was noted as tapped volume (Vt). The bulk and tap densities were calculated using the equation:

$$
\begin{aligned}
& \operatorname{Bulkdensity}(B)=\frac{M}{V_{0}} \\
& \text { Tapped density }(T)=\frac{M}{V t}
\end{aligned}
$$

\section{Hausner's ratio $(H)$}

$\mathrm{H}$ was calculated as the ratio of tap density to bulk density of the sample.

$$
\mathrm{H}=\frac{\mathrm{T}}{\mathrm{B}}
$$

Compressibility index (C \%)

$\mathrm{C} \%$ was calculated using the following equation:

$$
\mathrm{C} \%=\frac{\mathrm{T}-\mathrm{B}}{\mathrm{T}} \times 100
$$

Effective pore radius $\left(R_{\text {eff.p }}\right)$

The $R_{\text {eff. }}$ of OFG powder was predictable according to the method reported by Jindal et al., 2013 [25]. Micropipette tip was filled with OFG powder and weighed $\left(\mathrm{W}_{\mathrm{N}}\right)$. Then, $\mathrm{n}$-hexane (surface tension $(\gamma)$ $18.4 \mathrm{~N} / \mathrm{m}, \theta=0^{\circ}$ ) was added dropwise to the top of packed bed till the solvent filtered out at the bottom of the tip. The tip was weighed again weighed $\left(\mathrm{W}_{\mathrm{B}}\right)$. The $\mathrm{R}_{\text {eff.p }}$ was calculated using formula:

$$
\text { Reff.p }=\frac{\mathrm{W}_{\mathrm{B}}-\mathrm{W}_{\mathrm{A}}}{2 \pi \gamma}
$$

Loss on drying (LOD\%)

OFG sample ( $2 \mathrm{~g}$ ) was positioned in a tarred Petri dish and dried in oven at $105^{\circ} \mathrm{C}$, till constant weight was obtained $[2,27,28]$. The sample was 
then removed, weighed and moisture content was determined using the equation:

$$
\mathrm{LOD} \%=\frac{\mathrm{W}_{\mathrm{i}}-\mathrm{W}_{\mathrm{f}}}{\mathrm{W}_{\mathrm{i}}} \times 100
$$

Where, $W_{i}$ is the initial weight of sample and $W_{f}$ is the final weight after drying.

\section{Total ash content}

Total ash content of powder was estimated according to the method reported by Jindal et al., 2013 [25]. The gum sample (1.0 g) was weighed into a preignited and preweighed crucible, and transferred into a furnace at ignition temperature $550^{\circ} \mathrm{C}$ for $24 \mathrm{hrs}$. The recovered ash was transported into a desiccator for equilibration to room temperature before weighing. The resultant ash from the above was mixed with distilled water, boiled, filtered, and the filter was rinsed. Both filter paper and residue were transferred into the crucible and ignited for 24 hrs until a constant weight was reached. Thereafter, cooling was carried out in a desiccator and the product was weighed. Percent total ash was calculated from the formula:

$$
\% \text { Total ash }=\frac{\text { Ash weight }}{\text { Original sample weight }} \times 100
$$

\section{pH determination}

OFG dispersion $1 \% \mathrm{w} / \mathrm{v}$ was stirred constantly in water for 5 minutes and $\mathrm{pH}$ meter was used to determine $\mathrm{pH}$.

\section{Electrical properties \\ Zeta potential and conductivity studies of OFG sample}

The zeta potential and conductivity studies of OFG were conducted using Zetasizer (Malvern Instrument Ltd., UK). The zeta potential measurements were performed using an aqueous dip cell in an automatic mode maintaining the temperature of samples at $25^{\circ} \mathrm{C}$ and diluting the samples with triple distilled water and placing in the capillary measurement cell. Each sample was analyzed in triplicate and results were recorded as the average \pm standard deviation of the experimental values.

\section{Particle size measurement}

After diluting OFG sample with triple distilled water, it was measured for particle size and polydispersity index (PI) using a Zetasizer 4 (Malvern Instrument Ltd., UK) at $25^{\circ} \mathrm{C}$, scattering angle $90^{\circ}, 180$ seconds. The mean diameter was determined in triplicate. Cumulative analysis was used for generating the mean hydrodynamic diameter.

\section{Scanning electron microscopy (SEM) of OFG}

OFG samples were mounted on a clean aluminum stub with silver PAG-915 and coated with gold particles in the presence of argon gas. The OFG sample was then pictured using scanning electron microscope (LEO 435VP, Cambridge, UK) using a $15 \mathrm{kV}$ accelerating voltage, a 1-10 $\mu \mathrm{m}$ working distance and probe current of $3 \times 10^{-11} \AA$.

\section{Chemical properties of OFG sample}

Degree of esterification (\%DE)

The titrimetric method was used to determine the degree of esterification of OFG sample. OFG sample (500 mg) was sprinkled with $2 \mathrm{ml}$ of ethanol and dissolved in $100 \mathrm{ml}$ of HPLC water. Few drops of phenolphthalein were then added to the dissolved sample and titration was done with $0.5 \mathrm{M}$ sodium hydroxide. The volume of sodium hydroxide consumed was recorded as the initial titer, I. Thereafter, $10 \mathrm{ml}$ of $0.5 \mathrm{M}$ sodium hydroxide was added; the sample was robustly shaken and left uninterrupted for 10 minutes. 0.5 M hydrochloric acid $(10 \mathrm{ml})$ was added, accompanied with shaking, until the disappearance of pink color. Titration of solution containing Phenolphthalein (five drops) was done with $0.5 \mathrm{M}$ sodium hydroxide till the appearance of a faint pink color that persisted after vigorous shaking (final titer, $F_{t}$ ). The volume of titration was recorded as the saponification titer (the final titer). Each $\mathrm{ml}$ of $0.5 \mathrm{M}$ sodium hydroxide used in the saponification titer and the total titration (sum of initial titer and saponification titer) was equivalent to $97.07 \mathrm{mg}$ of galacturonic acid. The degree of esterification of OFG was calculated from the following formula:

$$
\% \mathrm{DE}=\frac{\text { Theinitial titer, } \mathrm{I}_{\mathrm{t}}}{\text { Theinital titer, } \mathrm{I}_{\mathrm{t}}+\text { the final titer }\left(\mathrm{F}_{\mathrm{t}}\right)} \times 100
$$

\section{Antioxidant activity of OFG}

\section{Hydrogen peroxide scavenging assay of $O F G$}

The method proposed by Xiong et al., 2013 [29]; Yao et al., 2013 [30]; Kamboj and Rana, 2014 [31]; Nehete and Bhatia, 2011 [32]. was used to measure the activity of OFG to scavenge $\mathrm{H}_{2} \mathrm{O}_{2}$. For this, a $40 \mathrm{mM}$ solution of $\mathrm{H}_{2} \mathrm{O}_{2}$ was prepared in phosphate buffer solution using $\mathrm{Na}_{2} \mathrm{HPO}_{4}^{-}$ $\mathrm{NaH}_{2} \mathrm{PO}_{4}(\mathrm{pH}=7.40,0.2 \mathrm{~mol} / \mathrm{L})$. Concentration of $\mathrm{H}_{2} \mathrm{O}_{2}$ was determined spectrophotometrically at $230 \mathrm{~nm} . \mathrm{H}_{2} \mathrm{O}_{2}$ solution $(0.6 \mathrm{ml}, 40 \mathrm{mM})$ was added to OFG samples of various concentrations $(0.1-10.0 \mathrm{mg} / \mathrm{ml})$ in distilled water. The absorbance of $\mathrm{H}_{2} \mathrm{O}_{2}$ at $230 \mathrm{~nm}$ was determined after 10 minutes against a blank solution containing phosphate buffer without $\mathrm{H}_{2} \mathrm{O}_{2}$. The antioxidant activity of various samples to scavenge $\mathrm{H}_{2} \mathrm{O}_{2}$ was calculated using the following equation:

$$
\% \mathrm{SE}=1-\frac{\mathrm{Abs}_{\text {sample } 230}}{\mathrm{Abs}_{\text {control } 230}}
$$

Where, SE is scavenging effect, $\mathrm{Abs}_{\text {sample } 230}$ and $\mathrm{Abs}_{\text {blank } 230}$ is Absorbance at $230 \mathrm{~nm}$ of sample solution and blank solution, respectively.

\section{Reducing power determination of OFG}

The method reported by Nehete and Bhatia, 2017 [32]; Xiong et al., 2013 [29]; Yao et al., 2013 [30] was used to determine the reducing power of OFG. Different concentrations $0.1-10.0 \mathrm{mg} / \mathrm{ml}$ of $\mathrm{OFG}$ $(2.0 \mathrm{ml})$ were mixed with $2.5 \mathrm{ml}$ sodium phosphate buffer $(\mathrm{pH}=6.60$, $0.2 \mathrm{M})$ and $2.5 \mathrm{ml}$ potassium ferricyanide $(1 \% \mathrm{w} / \mathrm{v})$, respectively. The mixtures were incubated for $20 \mathrm{~min}$ at $50^{\circ} \mathrm{C}$, cooled down in ice-cold water and then $2.5 \mathrm{ml}$ trichloroacetic acid $(10 \%, \mathrm{w} / \mathrm{v})$ was added to the mixtures, followed by centrifugation at $3000 \mathrm{rpm}$ for 10 minutes. $2.0 \mathrm{ml}$ supernatant was mixed with $2.5 \mathrm{ml}$ distilled water, $0.5 \mathrm{ml}$ ferric chloride solution $(0.1 \%, \mathrm{w} / / \mathrm{v})$ and the absorbance of this mixture was measured at $700 \mathrm{~nm}$.

\section{RESULTS AND DISCUSSION}

\section{Phytochemical screening of OFG sample}

The existence of polysaccharides was confirmed by the formation of red color with Ruthenium red and violet ring at the intersection of two liquids on reaction with Molisch reagent. The absence of blue color on treatment with iodine solution inferred the sample to be free of $\operatorname{starch}[2,27]$.

\section{Characterization of OFG sample Swelling index}

Swelling index of OFG sample is shown in Table 1. The swelling index of OFG sample was investigated in $0.1 \mathrm{~N} \mathrm{HCl}, \mathrm{pH} 1.2,6.8,7.4$ and water. The swelling of OFG sample was observed to pursue an increase with increase in $\mathrm{pH}$ of buffer from 1.2 to 7.4. The swelling index of OFG in different media followed the order water $>\mathrm{pH} 7.4>\mathrm{pH} 6.8>\mathrm{pH} 1.2>$ $\mathrm{pH} 10.0>\mathrm{HCl}(0.1 \mathrm{~N})$. This can be explained as that at low $\mathrm{pH}$ values (pH 1.2) the polymer network retained in its collapsed state due to the minimal/partial ionization of carboxyl group. This established the low swelling of the polymer [2,32]. However, as the $\mathrm{pH}$ increased to 7.4, the swelling of OFG increased. This could be credited to higher ionization of carboxyl group in polymer resulting in an increased intraionic 
Table 1: Swelling index, solubility, WST, powder flow properties, pH and LOD of OFG sample

\begin{tabular}{ll}
\hline Parameter & Results \\
\hline WST & $182 \pm 6.21$ seconds \\
Moisture content & $0.65 \pm 0.04 \mathrm{w} / \mathrm{w}$ \\
Angle of repose & $34.21 \pm 0.61$ \\
Bulk density & $0.42 \pm 0.03$ \\
Tapped density & $0.48 \pm 0.04$ \\
Compressibility index & $12.5 \% \pm 0.12$ \\
Hausner ratio & $1.14 \pm 0.09$ \\
Effective pore radius & $9.31 \times 10^{-1} \mathrm{~mm}$ \\
pH & $6.4 \pm 0.2$ \\
LOD (\%w/w) & 11.9 \\
Swelling index & \\
Water & $5.40 \pm 0.35$ \\
0.1 N HCl & $1.43 \pm 0.20$ \\
pH 1.2 & $2.50 \pm 0.25$ \\
pH 6.8 & $3.42 \pm 0.42$ \\
pH 7.4 & $4.81 \pm 0.31$ \\
pH 10.0 & $2.45 \pm 0.24$ \\
Solubility (\%) & \\
pH 2.0 & $59.51 \pm 0.80$ \\
pH 3.0 & $62.15 \pm 0.82$ \\
pH 4.5 & $66.14 \pm 0.75$ \\
pH 5.0 & $74.29 \pm 0.87$ \\
pH 5.5 & $81.12 \pm 1.02$ \\
pH 6.8 & $89.23 \pm 1.89$ \\
pH 7.4 & $94.15 \pm 1.54$ \\
pH 10.0 & $73.92 \pm 1.48$ \\
Water & Sparingly soluble \\
Acetone & Insoluble \\
Ethanol & Insoluble \\
Chloroform & \\
\hline & \\
\hline &
\end{tabular}

LOD: Loss on drying, OFG: Okra fruit gum, WST: Water sorption time

repulsion. Also at higher $\mathrm{pH}$, swelling decreased, which might be due to dissolution of ionic linkages within the polymer structure resulting in breaching of its intact network [33].

It is well known that low swelling in acidic $\mathrm{pH}$ restricts the release of drugs from dosage forms, and high swelling in alkaline $\mathrm{pH}$ would be useful for sustaining the drug release as the dosage form travels down the gastrointestinal tract [25]. Thus, the swelling behavior of OFG can be established to be useful for regulating the drug release from dosage forms.

\section{Solubility}

Solubility of OFG powder was observed to follow a similar trend as that of swelling index (Table 1). An increase in solubility with increase in $\mathrm{pH}$ of buffer from 2.0 to 7.4 was observed. The low solubility of the polymer at low $\mathrm{pH}$ values can be due to the minimal/partial ionization of carboxyl group and the polymer network retained in its collapsed state [2]. However, as the $\mathrm{pH}$ increased to 7.4, solubility of OFG increased as at higher $\mathrm{pH}$, higher ionization of carboxyl group in polymer result in an increased intraionic repulsion. Solubility decreased with further increase in $\mathrm{pH}$ which may be due to dissolution of ionic linkages within the polymer structure ensuing breaching of its intact network [2].

OFG was pragmatic to be scarcely soluble in water and insoluble in acetone, chloroform, and ethanol. At high temperature, an augment in solubility was observed. OFG produced cluttered gum in acetone. This suggested acetone to be good precipitating agent to fabricate dried okra. OFG powder swelled and shaped sticky dispersion in water. The slightly soluble behavior of OFG is useful in controlled release formulation as the viscous distribution stand for a strong matrix polymeric system that can control the discharge of exceedingly soluble drug in the stomach.
WST

The dried OFG had $0.65 \% \mathrm{w} / \mathrm{w}$ of moisture content. Poor moistening capability of OFG is indicated by high WST of 182 seconds. Poor moistening capability and low moisture content make it suitable to use it in the presence of moisture sensitive ingredients and during storage.

\section{Packing and flow properties}

The bulk and tapped densities give an insight into the packing arrangement of the particle and the compaction profile of a material [25,34]. The compressibility index and angle of repose of OFG were found to be $12.5 \%$ and $34.21^{\circ}$ (Table 1), respectively. Compressibility values lying between 11 and 15 indicate good flow character [34]. Further, angle of repose values between $31^{\circ}$ and $35^{\circ}$ is good; $36^{\circ}$ and $40^{\circ}$ indicate fair flow character with no need of adding flow promoter. The results indicated good flow properties as compressibility's index, Hausner ratio, and angle of repose (Table 1) are in the range of good flow characteristics according to USP30 NF25. Therefore, good flow behavior of OFG particles is suggested by the results obtained, and no need of addition of flow promoters during formulation processing is suggested.

Porosity of powder is indicated by effective pore radius. Berger et al., (2012) [35] reported $R_{\text {eff }}$ of Cassia fistula gum (CFG) $\left(2.72 \times 10^{-1} \mathrm{~mm}\right)$, carboxymethylated CFG $\left(3.04 \times 10^{-1} \mathrm{~mm}\right)$, and carbamoylethylated CFG $\left(3.42 \times 10^{-1} \mathrm{~mm}\right)$. These were observed to exhibit good wicking properties, which increased with increase in $R_{\text {effp }}$ suggesting their super disintegration potential. Hence, $R_{\text {eff.p }}$ of $9.31 \times 10^{-1} \mathrm{~mm}$ (Table 1 ) suggests high porosity and good compressibility in comparison to $\mathrm{R}_{\text {eff }}$ of CFG $\left(2.72 \times 10^{-1} \mathrm{~mm}\right)$, carboxymethylated CFG $\left(3.04 \times 10^{-1} \mathrm{~mm}\right)$, and carbamoylethylated CFG $\left(3.42 \times 10^{-1} \mathrm{~mm}\right)$ which were observed to exhibit good wicking properties, which increased with increase in $R_{\text {eff.p }}$ suggesting their super disintegration potential.

\section{$L O D$}

The LOD of OFG sample on drying was found to be $11.8 \%(\mathrm{w} / \mathrm{w})$. This value suggests thermostable nature of OFG sample which was also confirmed from the differential scanning calorimetry (DSC) studies as no signs of degradation were observed till $195^{\circ} \mathrm{C}$.

\section{Ash content}

The total ash and soluble ash content were found to be $1.0 \%$ and $0.24 \% \mathrm{w} / \mathrm{w}$, respectively. The lower ash value indicates low levels of contamination in the finally obtained OFG.

\section{$p H$}

Okra gum was found to have neutral $\mathrm{pH}$ (Table 1). At neutral $\mathrm{pH}$ range OFG is known to have maximum viscosity and thus helps in the retarding effect for the development of sustained release tablets. Neutral $\mathrm{pH}$ also causes minimum irritation to the gastrointestinal tract and is suitable use in formulation employing acidic, basic and neutral drugs [36].

\section{Electrical properties \\ Zeta potential studies and particle size measurement of OFG}

Particle size analysis stand for mean diameter of total population of the particles and PI is measure of particle size distribution. The PI of OFG ranges from 0.00 (monodisperse) to 0.545 (very broad particle size distribution). The average mean diameter of OFG was found to be $256.3 \mathrm{~nm}$ with PI of 0.395 indicating narrow particle size distribution and small mean particle size. Aqueous dispersions of OFG exhibited zeta potential of $-9.85 \mathrm{mV}$ indicate its anionic character. The negative zeta potential of OFG proposes its applicability in imposing gum-polymer or gum-ion interactions for regulating drug release character.

\section{SEM images of OFG sample}

Scanning electron microscopic images of OFG powder (Fig. 2) revealed irregular, rough surfaced, and amorphous structure of OFG powder. 
Chemical properties of OFG sample

\section{Degree of esterification}

Titrimetric method was used to determine degree of esterification of OFG. 7.8 was found to be the degree of $-\mathrm{COOH}$ of esterification in OFG.

\section{Antioxidant activity of OFG}

Hydrogen peroxide scavenging assay of OFG

As Hydrogen peroxide may give rise to hydroxyl radical in the cells, it can sometimes be toxic to cells. $\mathrm{H}_{2} \mathrm{O}_{2}$ can cross cell membranes rapidly and once inside the cell, it can potentially react with $\mathrm{Fe}^{2+}$ or $\mathrm{Cu}^{2+}$ to form hydroxyl radicals, and this may be the origin of many of its toxic effects in neuronal cells. It is, therefore, advantageous for cells to control the amount of $\mathrm{H}_{2} \mathrm{O}_{2}$ that is allowed to accumulate [29,31]. The scavenging activity of OFG $(0.1-10.0 .0 \mathrm{mg} / \mathrm{ml})$ on $\mathrm{H}_{2} \mathrm{O}_{2}$ is shown in Fig. 3. The inhibitory concentration $50 \%$ (IC IC $_{50}$ of OFG was $1.6 \mathrm{mg} / \mathrm{ml}$, while $\mathrm{IC}_{50}$ for ascorbic acid was $0.2 \mathrm{mg} / \mathrm{ml}$. The hydroxyl radical scavenging activity of guar gum was only $30 \%$ at $5 \mathrm{mg} / \mathrm{ml}$. However, this activity of sulfated derivative of guar gum and xanthan oligosaccharides; xanthan oligosaccharides (XGOS-A) or XGOS-B was reported to be $50 \%$ at 7.79 , 2.5 and $9.4 \mathrm{mg} / \mathrm{ml}[29,37]$. This suggested higher hydroxyl radical scavenging activity of CFG. Ascorbic acid and pyruvate acid were used as a control and their $\mathrm{IC}_{50}$ were 0.26 and $0.37 \mathrm{mg} / \mathrm{mL}$, respectively.

\section{Reducing power of $\mathrm{OFG}$}

Reducing power assay has been used to evaluate the ability of antioxidants to donate electrons. Antioxidant compounds cause the reduction of ferric $\left(\mathrm{Fe}^{3+}\right)$ form to the ferrous $\left(\mathrm{Fe}^{2+}\right)$ form because of their reductive capabilities. Prussian blue-colored complex is formed by adding $\mathrm{FeCl}_{3}$ to the ferrous $\left(\mathrm{Fe}^{2+}\right)$ form. Therefore, reducing power can be determined by measuring the formation of Perls' Prussian blue at $700 \mathrm{~nm}$. In this experiment, yellow color of the test solution changes to green or blue color depending on the reducing power of antioxidant samples. Similarly, higher absorbance indicates higher ferric reducing power and hence high antioxidant activity $[29,38]$. Fig. 4 summarizes the results of reducing power of $\mathrm{OFG}$. The absorbance of OFG solutions increases with the increase in OFG concentrations. The maximum absorbance (0.5424) was obtained at $10 \mathrm{mg} / \mathrm{ml} \mathrm{OFG}$ solution concentration. The absorbance of corn flour gum at the same concentration was 0.5199 [31] which proves that okra gum has better reducing power than corn flour gum.

\section{CONCLUSION}

Ultrasound assisted extraction technology was used for extraction of OFG to enhance the extraction yield. Optimization of optimal extraction conditions was done by single factor design and Box-Behnken design (BBD). The optimum extraction conditions given BBD were as follows: Ratio of water to raw material $44.98 \mathrm{~mL} / \mathrm{g}$; ultrasonic power, $60 \mathrm{~W}$; and extraction time, 40 minutes. The experimental yield obtained under these conditions was $31.52 \% \pm 0.22 \%(n=3)$, which was identical to the predicted value as well. OFG was associated with low ash value and high WST. The particles were rough and displayed a narrow range of particle size distribution. A reasonable negative charge of $-9.85 \mathrm{mV}$ and high value of degree of esterification (7.8) recommended its possible use in dosage forms for regulating release of drug through gum-polymer or gum-ion interaction. Attenuated total reflection-Fourier transform infrared and ${ }^{1} \mathrm{H}$ NMR analysis were performed to determine the main the functional groups of OFG. Amorphous nature of OFG is explained by XRD spectra and DSC studies recommended higher thermal stability of OFG. Micromeritic properties, effective pore radius and swelling index of OFG confirm its porous nature which suggested use of OFG as diluents in various pharmaceutical preparations. The antioxidant activity of OFG was higher compared to corn flour gum. Thus, OFG could be researched as natural antioxidant food ingredients and also for application in medicine and health care products.

\section{ACKNOWLEDGMENT}

The authors are thankful to I.K. Gujral Punjab Technical University, Punjab, India, for supporting the research project.

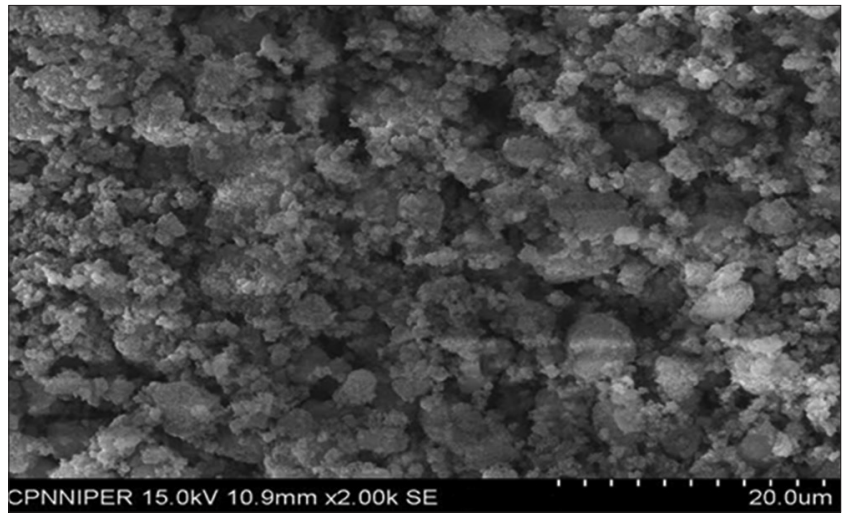

Fig. 2: Scanning electron microscopy image of pure okra fruit gum at $\times 2.00 \mathrm{k}$

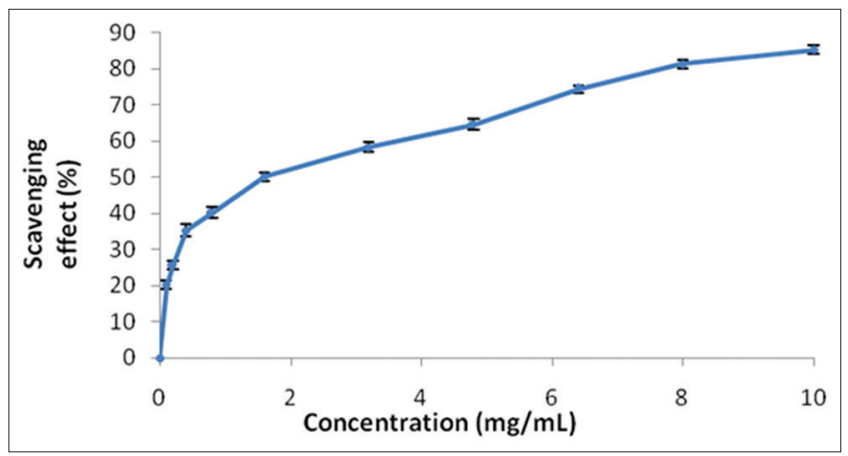

Fig. 3: Antioxidant potential of okra fruit gum by hydrogen peroxide radical scavenging activity

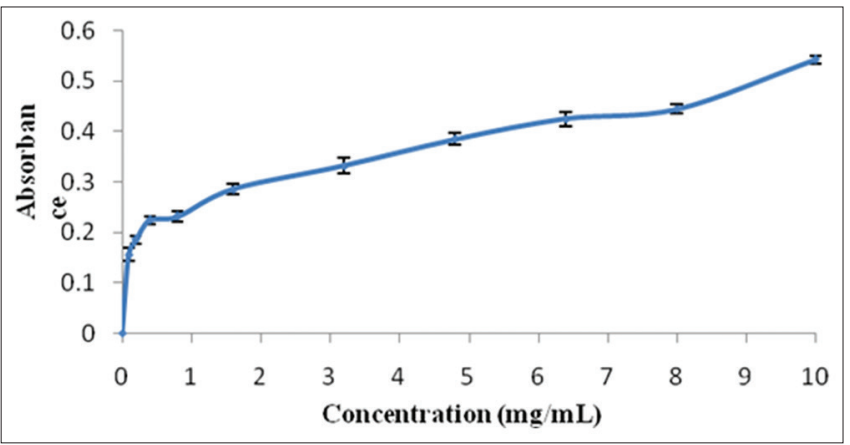

Fig. 4: Reducing power of okra fruit gum sample

\section{REFERENCES}

1. Kipping T, Rein H. Continuous production of controlled release dosage forms based on hot-melt extruded gum arabic: Formulation development, in vitro characterization and evaluation of potential application fields. Int J Pharm 2016;497(1-2):36-53.

2. Kaur G, Singh D, Brar V. Bioadhesive okra polymer based buccal patches as platform for controlled drug delivery. Int J Biol Macromol 2014;70:408-19.

3. Paradkar M, Gajra B, Patel B. Formulation development and evaluation of medicated chewing gum of anti-emetic drug. Saudi Pharm J 2016;24(2):153-64.

4. Sharma N, Deshpande RD, Sharma D, Sharma RK. Development of locust bean gum and xanthan gum biodegradable microparticles of celecoxib using a central composite design and its evaluation. Ind Crops Prod 2016;82:161-70.

5. Bernela M, Ahuja M, Thakur R. Enhancement of anti-inflammatory activity of bromelain by its encapsulation in katira gum nanoparticles. Carbohydr Polym 2016;143:18-24.

6. Najafi MN, Hosaini V, Mohammadi-Sani A, Koocheki A. Physical 
stability, flow properties and droplets characteristics of Balangu (Lallemantia royleana) seed gum/whey protein stabilized submicron emulsions. Food Hydrocoll 2016;59:2-8.

7. Salunke SR, Patil SB. Ion activated in situ gel of gellan gum containing salbutamol sulphate for nasal administration. Int $\mathrm{J}$ Biol Macromol 2016;87:41-7.

8. Sinha P, Ubaidulla U, Nayak AK. Okra (Hibiscus esculentus) gumalginate blend mucoadhesive beads for controlled glibenclamide release. Int J Biol Macromol 2015;72:1069-75.

9. Mishra A, Clark JH, Pal S. Modification of okra mucilage with acrylamide: Synthesis, characterization and swelling behavior. Carbohydr Polym 2008;72:608-15.

10. Sengkhamparn N, Verhoef R, Schols HA, Sajjaanantakul T, Voragen AG. Characterisation of cell wall polysaccharides from okra (Abelmoschus esculentus (L.) Moench). Carbohydr Res 2009;344(14):1824-32.

11. Samavati V. Central composite rotatable design for investigation of microwave-assisted extraction of okra pod hydrocolloid. Int J Biol Macromol 2013;61:142-9.

12. Costandino AJ, Romanchick-Cerpoviez JE. Okra polysaccharides as egg white substitute. J Am Diet Assoc 2004;104:44-8

13. Romanchick-Cerpoviez JE, Tilmon RW, Baldree K. Okra polysaccharides as fat replacer in chocolate and cookies. J Am Diet Assoc 2002;102(9):1301-3.

14. Alamri MS, Mohamed AA, Hussain S. Effects of alkaline-soluble okra gum on rheological and thermal properties of systems with wheat or corn starch. Food Hydrocoll 2013;30:541-51.

15. Alqasoumi SI. 'Okra' Hibiscus esculentus L.: A study of its hepatoprotective activity. Saudi Pharm J 2012;20(2):135-41.

16. Gürbüz I, Ustün O, Yesilada E, Sezik E, Kutsal O. Anti-ulcerogenic activity of some plants used as folk remedy in Turkey. J Ethnopharmacol 2003;88(1):93-7.

17. Kalu VD, Odeniyi MA, Jaiyeoba KT. Matrix properties of a new plant gum in controlled drug delivery. Arch Pharm Res 2007;30(7):884-9.

18. Newton AM, Indana VL, Kumar J. Chronotherapeutic drug delivery of Tamarind gum, Chitosan and Okra gum controlled release colon targeted directly compressed Propranolol $\mathrm{HCl}$ matrix tablets and in-vitro evaluation. Int J Biol Macromol 2015;79:290-9.

19. Uhiara NS, Onwuka G. Suitability of protein-rich extract from okra seed for formulation ready to use therapeutic foods (RUTF). Niger Food J 2014;32:105-9.

20. Ogaji I. Some physicochemical properties of acetaminophen pediatric suspensions formulated with okra gums obtained from different extraction process as suspending agent. Asian J Pharmacol 2011;5:15-20.

21. Ogaji I, Nnoli O. Film coating potential of okra gum using paracetamol as a model drug. Asian J Pharmacol 2010;4(2):130-4.

22. Wang Y, Liu Y, Hu Y. Optimization of polysaccharides extraction from Trametes robiniophila and its antioxidant activities. Carbohydr Polym 2014;111:324-32.
23. Vilkhu K, Mawson R, Simons L, Bates D. Applications and opportunities for ultrasound assisted extraction in the food industry - A review. Innov Food Sci Emerg Technol 2008;9(2):161-9.

24. Xu Y, Zhang L, Bailina Y, Ge Z, Ding T, Ye X, et al. Effects of ultrasound and/or heating on the extraction of pectin from grapefruit peel. J Food Eng 2014;126:72-81.

25. Jindal M, Kumar V, Rana V, Tiwary AK. Exploring potential new gum source Aegle marmelos for food and pharmaceuticals: Physical, chemical and functional performance. Ind Crops Prod 2013;45:312-8.

26. Vora N, Rana V. Preparation and optimization of mouth/orally dissolving tablets using a combination of glycine, carboxymethyl cellulose and sodium alginate: A comparison with superdisintegrants. Pharm Dev Technol 2008;13(3):233-43.

27. Deveswaran R, Marabathuni VJ, Bharath S, Basavaraj BV, Madhavan V. Studies on hibiscus esculentus mucilage as a pharmaceutical excipient. Int J Innov Pharm Sci 2011;2:8-17.

28. Emeje M, Isimi C, Byrn S, Fortunak J, Kunle O, Ofoefule S. Extraction and physicochemical characterization of a new polysaccharide obtained from the fresh fruits of abelmoschus esculentus. Iran J Pharm Res 2011;10(2):237-46

29. Xiong X, Li M, Xie J, Jin Q, Xue B, Sun T. Antioxidant activity of xanthan oligosaccharides prepared by different degradation methods. Carbohydr Polym 2013;92(2):1166-71.

30. Yao XC, Cao Y, Wu SJ. Antioxidant activity and antibacterial activity of peach gum derived oligosaccharides. Int J Biol Macromol 2013;62:1-3.

31. Kamboj S, Rana V. Physicochemical, rheological and antioxidant potential of corn fiber gum. Food Hydrocoll 2014;39:1-9.

32. Nehete J, Bhatia M. Correlation of antioxidant activity with phenolic content and isolation of antioxidant compound from Lygodium flexuosum (L.) SW extracts. Int J Pharm Pharm Sci 2011;3:48-52.

33. Meera G, Leenamma J, Josekumar VS. Antioxidant, anti-lipid peroxidative and antimicrobial properties of the epiphytic fern, Pyrrosia heterophylla (L.) Int J Pharm Pharm Sci 2017;9:87-93.

34. Singh B, Sharma N. Development of novel hydrogels by functionalization of sterculia gum for use in anti-ulcer drug delivery. Carbohydr Polym 2008;74:489-97.

35. Berger J, Reist M, Mayer JM, Felt O, Peppas NA, Gurny R. Structure and interactions in covalently and ionically crosslinked chitosan hydrogels for biomedical applications. Eur J Pharm Biopharm 2004;57(1):19-34

36. Wells JI, Aulton ME. Pharmaceutical preformulation. In: Aulton ME, editor. Pharmaceutics: The Design and Manufacture of Medicines. Philadelphia, PA: Churchill Livingstone; 2007. p. 356.

37. Vinod VT, Sashidhar RB, Suresh KI, Rao BR, Saradhi UV, Rao TP. Morphological, physicochemical and structural characterization of gum kondagogu (Cochlospermum gossypium): A tree gum from India. Food Hydrocoll 2008;22(5):899-915.

38. Sinha VR, Al-Azaki AA, Kumar RV. Novel lannea woodier gum matrices for controlled release of drugs. Carbohydr Polym 2011;83:1492-8. 